\title{
Hydroxamate Siderophore from Bacillus sp SD12 Isolated from Iron Factory Soil
}

\author{
M. RADHAKRISHNAN ${ }^{1}$, K.J. SAMSHATH ${ }^{2}$ and R. BALAGURUNATHAN ${ }^{3 *}$ \\ ${ }^{1}$ Centre for Drug Discovery and Development, Sathyabama University, \\ Chennai- 600 119, Tamil Nadu, India. \\ 2Department of Microbiology, Sri Sankara Arts \& Science College, \\ Kanchipuram - 631 561, Tamil Nadu, India. \\ ${ }^{3}$ Department of Microbiology, Periyar University, Salem - 636 011. Tamil Nadu, India.
}

http://dx.doi.org/10.12944/CWE.9.3.53

(Received: November 08, 2014; Accepted: November 29, 2014)

\begin{abstract}
The present study reports siderophores production from bacteria isolated from Iron factory soil and its antifungal activity. Of the twelve morphologically different bacterial cultures isolated from iron factory soil, Kanchipuram, only two strains SD6 and SD12 showed siderophores production in Chrome Azurol S assay. Strain SD12 which showed maximum siderophores production, was selected for further studies. Siderophores produced by the strain SD12 was identified as hydroxymate type. Partial purification was carriedout by ammonium sulphate precipitation and dialysis. The molecular weight of partially purified siderophores was found to be $80 \mathrm{KDa}$ and it showed good antifungal activity against Fusarium solani, Aspergillus niger and Phythium sp. The potential strain was identified as Bacillus sp SD12 based on their phenotypic characteristics. Further purification and characterization of siderophores from strain SD12 pave the way for its utilization in the field of medicine and agriculture.
\end{abstract}

Key words: Siderophore, CAS assay, Bacillus, ion factory soil, antimicrobial

\section{INTRODUCTION}

Most bacteria have evolved a diverse series of high-affinity iron acquisition systems that are dependent upon the synthesis and/or uptake of low molecular weight iron chelators termed siderophores ${ }^{1}$. Siderophores and their substituted derivatives have a large number of applications in agricultural, environmental and medical sciences. In agriculture, application of siderophores producing bacteria leads to increase in soil fertility and biocontrol of fungal pathogen. The most important application is selective drug delivery, a Trojan horse strategy, to defeat drug resistant bacteria. The Trojan horse strategy is most promising way to specifically attack multiple antibiotic resistant strains of bacteria associated with life threatening infections. Other major clinical applications include treatment of diseases like haemochromatosis, thalassemia, and dialysis encephalopathy ${ }^{2}$. Siderophore also used to reduce the level of metal contamination in environment specifically from soil and water.

Many different bacteria and fungi from different ecosystems are reported to produce different siderophores types. At present nearly 500 siderophores are reported from selected microorganisms. A great variation is seen in siderophores structure from one species to another ${ }^{3}$. The present study was undertaken for the production of siderophores from bacteria isolated from iron factory soil. 


\section{MATERIALS AND METHODS}

Sample collection and bacterial isolation:

Soil sample was collected from iron industry area, Kanchipuram using sterile polythene cover. Bacteria from the collected sample were isolated by standard spread plate method. Morphologically different bacterial colonies were selected, subcultured and maintained on nutrient agar slants at $4^{\circ} \mathrm{C}$ until further screening.

\section{Screening and production of siderophore:}

All the bacterial isolates were screened for siderophores production by Chrome Azurol S (CAS) method $^{4}$. All glasswares were soaked overnight in $6 \mathrm{~N} \mathrm{HCl}$ and rinsed with distilled water for several times to remove traces of iron. Freshly grown bacterial cultures are inoculated as spot on CAS agar plates and incubated at $28^{\circ} \mathrm{C}$ for $24-48$ hours. After incubation, siderophore production was confirmed by the presence of orange colour zone around the well on CAS agar plates.

Fresh grown bacterial cells from nutrient agar plates were inoculated into Fiss glucose minimal media supplemented with $300 \mu \mathrm{g} \mathrm{FeSo} 4$ and kept in rotary shaker for 24 hours. The whole medium was centrifuged at $5000 \mathrm{rpm}$ for 10 minutes and the cell free supernatant was collected in sterile screw capped tubes. About $100 \mu \mathrm{l}$ of CFS was loaded into a $5 \mathrm{~mm}$ sized well made on CAS agar plates. Sterile medium was also added as control and the plates were incubated at room temperature. Among the two strains tested, strain SD12 which showed maximum size of colour change was selected as potential strain for further studies.

\section{Siderophore typing:}

Detection of hydroxamate siderophores (Tetrazolium test):

This test is based on the capacity of hydroxamic acid to reduce tetrazolium salts by hydrolysis of hydroxamate group in presence of strong alkali. Instant appearance of a deep red colour on addition of tetrazolium salt and $\mathrm{NaOH}$ to the CFS was considered as positive for the presence of a hydroxamate siderophore ${ }^{5}$.
Detection of catecholate siderophores (Arnow's test):

Catecholate siderophores on reaction, in succession with nitrous acid, molybdate and alkali, yield a pink chromogen that absorbs maximally at $515 \mathrm{~nm}^{6}$.

\section{Detection of carboxylate siderophores} (Spectrophotometric test):

Carboxylate siderophores was detected by formation of copper complex which was observed for absorption maximum between $190-280 \mathrm{~nm}$. There is no specific wavelength at which the copper complex gets absorbed. The entire wavelength $190-280 \mathrm{~nm}$ was scanned to observe the peak of absorption of the siderophore ${ }^{7}$.

\section{Effect of selected media on siderophores production}

Ten percent inoculum of strain SD12 was transferred into King B medium prepared in three different compositions as recommended by Rachid et al. ${ }^{8}$. All the flasks were incubated in rotary shaker for 4 days. After incubation, the CFS (crude siderophores) was collected and confirmed for the presence of siderophore by CAS assay as described earlier. The cell free supernatant was acidified to $\mathrm{pH} 2$ using $6 \mathrm{M} \mathrm{HCl}$ and extracted using $1 / 4$ volume of ethyl acetate thrice. The ethyl acetate fractions were pooled together and concentrated using rotary vacuum evaporator. Quantity of crude siderophore was quantified and stored at $-20^{\circ} \mathrm{C}$.

\section{Partial purification of siderophores:}

The siderophore present in the CFS was separated by precipitation using saturated ammonium sulphate solution. The salt present in the precipitated protein was removed by dialysis. The dialysate was further tested for siderophore activity and typing. Molecular weight of the partially purified dialysate was determined by adopting standard SDS-PAGE analysis.

\section{Antifungal activity of siderophores:}

Antifungal activity of partially purified siderophores was determined by the method as described by Schorth and Hancock ${ }^{10}$. Test organisms used in this study include Fusarium sp., Aspergillus 
$s p$, and Phythium sp by well diffusion method. Zone of inhibition was measured after 72 hours of incubation at $28^{\circ} \mathrm{C}$.

\section{Characterization of potential strain:}

Phenotypic characteristics such as micromorphology, Grams reaction, presence of endospore, motility, cultural characteristics, enzymatic activities of potential strain was studied by adopting standard microbiological methods. The potential strain was identified at genus level by comparing its characteristics with the characteristics of known bacterial species given in the Bergeys Manual of Systematic Bacteriology.

\section{RESULTS AND DISCUSSION}

Totally 12 morphologically different bacterial colonies (SD1-SD12) were recovered, purified and subcultured using nutrient agar medium. In CAS assay, only two strains SD6 and SD12 showed positive reaction (orange colour zone) for siderophore production. The strain SD12 produced

Table. 1: Phenotypic characteristics of potential strain SD12

\begin{tabular}{lc}
\hline Characteristics & Strain SD12 \\
\hline Gram staining & Gram positive rods \\
Endospore & Present \\
Motility & Motile \\
Growth on nutrient agar & Irregular, mucoid, \\
& colourless colonies \\
Catalase & + \\
Oxidase & - \\
Urease & - \\
Amylase & + \\
Gelatinase & + \\
Indole & - \\
VP & + \\
Citrate & + \\
Glucose & + \\
Fructose & + \\
Mannitol & + \\
Xylose & + \\
Inositol & + \\
Starch & + \\
Temperature tolerance & + \\
Anaerobic Growth & - \\
\hline & \\
\hline
\end{tabular}

maximum of $15 \mathrm{~mm}$ sized orange colour zone in CAS plate. The CAS Assay ${ }^{4}$ is the universal chemical assay for siderophore detection and is based on a siderophore's high affinity for ferric iron. CAS plates are blue in color because chrome azurol $S$ dye is complexes with ferric iron. When siderophore is present, the following reaction occurs, which releases the free dye, which is orange in color.

In siderophore typing, the cell free supernatant (crude siderophore) of strain SD12 produced deep red colour in tetrazolium test. This result confirms that the siderophore produced by the strain SD12 is hydroxamate type. Hydroxamate siderophore are produced by bacteria and fungi. Most hydroxamate groups, $\mathrm{C}(=\mathrm{O}) \mathrm{N}-(\mathrm{OH}) \mathrm{R}$, where $\mathrm{R}$ is an amino acid or a derivative. Each hydroxamate group provides two oxygen molecules, which form a bidentate ligand with iron. Therefore, each siderophores forms a hexadentate octahedral complex with Fe3+. Hydroxamate siderophores usually show strong absorption between 425 and $500 \mathrm{~nm}$ when bound to iron. Ferrichrome produced by the fungus Ustilago sphaerogena, was the first siderophore to be isolated and shown to be a growth factor for other microorganisms ${ }^{11}$. The functional groups present in the hydroxamate siderophore produced by the strain SD12 was confirmed by further spectral and chromatographic analysis. Powell et al. ${ }^{12}$ have shown that hydroxamate siderophores are present in various soils and they are also produced in aquatic environments. Further excessive accumulation of heavy metals is toxic to most plants and contaminates the soil which result decreased soil microbial activity and soil fertility,

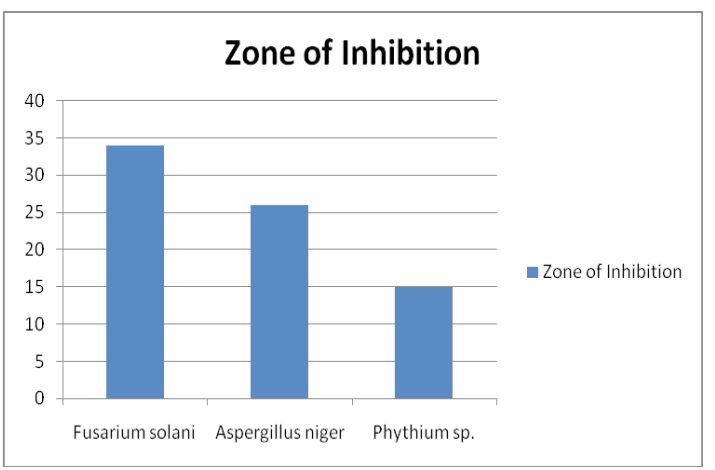

Fig. 1: Antiphytofungal activity of hydroxamate siderophore produced from the bacterial strain SD12 
and yield losses ${ }^{13}$. In this concern hydroxamate type siderophore present in soil play important role to immobilize the metals.

Among the three different media tested, the crude siderophore produced from the medium 3 showed maximum of $25 \mathrm{~mm}$ zone of orange colour zone. About $420 \mathrm{mg} / \mathrm{ml}$ of crude protein precipitate was obtained after ammonium sulphate precipitation and it yielded $190 \mathrm{mg}$ of partially purified siderophore after dialysis. Based on the results of SDS page analysis, in comparison with the standard marker protein, the molecular weight of siderophore produced by the strain SD12 was determined as 70-80 KDa.

Siderophores are themselves growth inhibitors of various phytopathogenic fungi, such as Phytophthora parasitica ${ }^{14}$, Phythium ultimum ${ }^{15}$ and Fusarium oxysporum veri dianthi. A direct correlation was established in vitro between siderophores synthesis in fluorescent pseudomonads and their capacity to inhibit germination of chlamydospores of $F$. oxysporum ${ }^{16}$. In antifungal activity testing the partially purified siderophores inhibited the growth of phytofungal pathogens such as Fusarium solani, Aspergillus niger and Phythium sp. (Figure 1)

The potential strain SD12 isolated in this study was Gram positive rod shaped, spore forming, motile bacteria. It also found to be catalase and nitrate reduction positive and oxidase negative. Based on the studied characteristics (Table 1), strain SD12 was identified as Bacillus sp. SD12. There are many authors reported the siderophores production and antiphytofungal activity of Bacillus sp. Pankajkumar et al. ${ }^{17}$ reported the siderophores production, phytofungal activity and other plant growth promoting properties of Bacillus strains isolated from rhizosphere soil. Bharucha et al. ${ }^{9}$ (2013) reported the antifungal activity of catecholate type siderophores by Bacillus sp isolated from the rhizosphere soil of Medicaco sativa (Alfalfa). The potential SD12 will be identified at species level based on their molecular characteristics.

Findings of the present study concluded that the potential Bacillus sp SD12 identified in this study is a potential candidate for the production of hydroxamate siderophores. Further purification and characterization of siderophores from strain SD12 pave the way for its utilization in the field of medicine and agriculture.

\section{ACKNOWLEDGEMENT}

Authors thank the Principal and the Management of Sri Sankara Arts \& Science College, Kanchipuram for the research facilities provided.

\section{REFERENCES}

1. Neilands JB. J. Biol. Chem. 270(45), 2672326726 (1995).

2. Nagoba B. and Vedpathak D., European J. Gen. Med. (3), 229-235 (2011)

3. Ali, S.S. and Vidhale N.N., Int. J. Curr. Microbiol. Appl. Sci. 2(12), 303-312 (2013)

4. Schwyn B. and Neilands J., Anal. Biochem. 160,47-56 (1987)

5. Snow GA., Bacteriol. Rev. 34, 99-125 (1970)

6. Arnow L.E., J. Biol. Chem. 118, 531-537 (1937)

7. Shenker M., Oliver I., Helmann M., Hadar Y. and Chen Y., J. Plant Nut. 15, 2173-2182 (1992)

8. Rachid D. and Bensoltane A., African J. Biotechnol. 4(7), 697-702 (2005)

9. Bharucha U.D., Patel K.C. and Trivedi U.B.,
Int. J. Res. Pharm. Sci. 4(4), 528-531 (2013)

10. Schroth M.N. and Hancock J.G., Annu. Rev. Microbiol. 35, 453-476 (1981)

11. Messenger A.J.M. and Ratledge, C. Edited by M Moo- Young (Pergamon press, New York), pp. 275-295 (1985)

12. Powell P.E., Cline G.R., Reid C.P.P. and Szaniszlo P.J., Nature. 287, 833-834 (1980)

13. McGrath S.P., Chaudri A.M. and Giller, K.E., J. Ind. Microbiol. 14(2), 94- 104 (1995)

14. Seuk C., Paulita T. and Baker R., J. Plant Pathol. 4(3), 218- 225 (1988)

15. Hamdan H., Weller D. and Thomashow L., Appl. Environ. Microbiol. 57(11),3270-3277 (1991)

16. Elad Y. and Baker R., Ecol. Epidemiol. 75, 1047-1052 (1985)

17. Pankaj Kumar, Dubey R.C. and Maheshwari D.K. Microbiol. Res. 167, 493- 499 (2012) 